\title{
Deforestation of the Principality of Serbia, 1830-1878: Overview
}

\author{
Momir SamardžićA*, Milivoj Bešlin ${ }^{B}$ \\ Received: May 15, 2016 | Revised: February 22, 2017 | Accepted: March 9, 2017 \\ DOI: $10.18421 / G P 21.01-01$
}

\begin{abstract}
The goal of this article is to trace the appearance of a pattern of forest mismanagement from the beginnings of modern Serbian state in the 19th century. The article will demonstrate that rapid demographic growth, accompanied by the expansion of arable land due to a gradual transition from animal husbandry to agriculture as the dominant form of economy, led to a vigorous increase in the process of deforestation in the period spanning from the attainment of autonomy (1830) to the wars against the Ottoman Empire (1876-1878). Supremacy of agriculture in the beginning of the 1870 s was achieved at the expense of forests, because the increase in agricultural yields in the peasant existential economy, which was characterized by underdeveloped agricultural techniques, meant a continuous expansion of arable land. The example of the Principality of Serbia confirms that in agrarian economies competition between the usufruct of the forest and its potential as agricultural land regularly ends with the removal of the forest.
\end{abstract}

Keywords: deforestation, floods, erosion, Serbia, $19^{\text {th }}$ century, agriculture, peasant economy

\section{Introduction}

At the end of 1899, the Ministry of National Economy of the Kingdom of Serbia issued an order for the establishment of a forest management administration provided by the Law on Forests from 1891. The Order was important because it symbolized the moment after which serious efforts to collect statistical data on Serbian forests followed. Although statistical data on forests began to be published after 1903 on an annual basis, they were incomplete (Statistical yearbook, 1906). The 1906 Report of the Ministry of National Economy, which contained the first data on a national level, demonstrated that at the time the state had no precise data on the territory covered by forests (Reports, 1907). A precise statistical account of the area covered by forests was essentially a task that had been unfulfilled by the statistical administration of the Principality/Kingdom of Serbia until the First World War. Data on forests appeared for the first time in national statistics in the census of 1889
(Statistical yearbook, 1894), and the first official data from the Forestry Department of the Ministry of National Economy (published in the aforementioned 1906 Report) noted that in $190531.4 \%$ of the country was covered by forests (Reports, 1907). Therefore, it is not possible to write statistically reliable observations about the dynamics of deforestation in Serbia's "long $19^{\text {th }}$ century", or for the time before the state's independence and territorial expansion in 1878. However, the importance of dealing with this phenomenon, regardless of the lack of statistical data, emanates from the analysis of researchers who, following the dynamics of the growth of arable land concluded that "in the early seventies the amount of cultivated land already exceeds the total area under forest" (Simeunović, 1957). Bearing in mind not only the rather short time frame (from autonomy to state independence), but also the fact that this was a period when, to a significant extent, the dynamics of the socio-economic processes was determined, the

\footnotetext{
A Department of History, Faculty of Philosophy, University of Novi Sad, Dr Zoran Djindjic Str. 2, 21000 Novi Sad, Serbia

B Institute for Philosophy and Social Theory, University of Belgrade

* Corresponding author: Momir Samardžić, e-mail: momir.samardzic@ff.uns.ac.rs
} 
causes and dynamics of deforestation become an interesting research issue because they reflect in a paradigmatic way the problems and dynamics of the development of agriculture as a dominant type of economy.

\section{Deforestation:}

\section{literary testimonies and dynamics}

As a landlocked country in the north of the Balkan Peninsula, the Principality of Serbia was dominated by hills and mountains. The Dinaric Alps mountain range to the southwest, the Carpathians to the northeast and the Balkan mountain range to the east and the southeast, as part of the "mountain chaos" of the peninsula (Buxton, 1908), all intersected in area of Serbia, giving the Principality the "appearance of a rough sea" (Karić, 1887). Serbia was a country sloping from south to north. According to a description of contemporary geographer Vladimir Karić, from the highest mountain peaks on the southern border (Mt. Kopaonik), the edges of the mountain ranges descended in waves northward toward the Sava River, disappearing into the plains or in the vast undulating plateaus of western Serbia. In the central part of the country, west of the mouth of the Morava River into the Danube, the mountain ranges extended to the banks of the Sava and Danube in waves of hills, while to the east, towards Golubac and the Iron Gate, the mountains disappeared into the Danube. Along with a gradual descent towards the north, the mountain ranges also diverged, making space for river valleys, from the Morava basin covering almost the entire territory of the Principality to the valleys of the bordering Drina, Sava, Danube and Timok Rivers (Karić, 1887).

Apart from the different levels of hydrographic dispersion from the southwest to the northeast, Serbia's moderate continental climate was marked by considerable climatic differences conditioned by the direction of the mountain ranges. To the southwest the influence of the Mediterranean climate area could be felt and the valley of Morava was exposed to climatic influences from Central Europe, while the Timok Region faced the consequences of geographical separation from the Morava Valley by the ranges of the Carpatho-Balkan Massif and exposure to climatic influences from the European east (Karić, 1887; Vlahović, 2011). Regardless of regional differences caused by various climatic influences, altitude, relief etc, it was a climate suitable for the development of flora characteristic of a moderate climatic zone. At the time of independence in 1878, the landscapes of Serbia, with their vast forests, fields and meadows not only in the plains, but also in the hills and mountain peaks, served as confirmation of this.
At the same time, the Serbian landscapes of 1870 s were a distinctive indicator of anthropogenic transformation as a consequence of economic development during previous decades. The population of the Principality in the $19^{\text {th }}$ century was predominantly agrarian. The geographical position at a crossroads of climatic influences, with its diversified and developed relief which further contributed to the modification of the method of distribution of climate and vegetation conditions, were a consequence of the diversity of the conditions of the emergence and development of soil, making the territory of the Principality a sort of pedological collection with fifteen different types of soil. The Šumadija (which included the Belgrade, Smederevo, Kragujevac, Jagodina and Rudnik districts) and Mačva (which included the Šabac, Valjevo and Podrinje districts) regions, as well as the western parts of Požarevac and Ćuprija districts and parts of Morava River Basin of the Aleksinac district, were parts of Serbia predominantly covered with soil that did not require significant amelioration or irrigation works and were, thus, most suitable for intensive agricultural production (Škorić, 1977). On the other hand, in the south of Serbia before the Treaty of Berlin, on the edges of the Dinaric Alps and border ridges of the mountains of Javor, Golija and Kopaonik were districts dominated by soil unsuitable for cultivation and with only small oases of fertile land. A characteristic example was the Užice district, with fertile land only in the smaller valleys of the Đetinja and Moravica rivers (History of T. Užice, 1989; Škorić, 1977). Consequently, more than half of the territory of the Principality could be counted as a soil of a high or satisfying level of fertility and suitable for crops with the use of different level and form of amelioration.

However, fertile land was also suitable for forest vegetation, so the period of Ottoman rule was marked by reforestation, while in the $19^{\text {th }}$ century the exploitation of its potential for agriculture was determined by the dynamics of the process of deforestation. Contemporary travelogue sources discuss the Principality's significant forestation at the time of autonomy. When traveling in 1833 from Niš to Belgrade, the French poet Alphonse de Lamartine wrote of the "ocean of Serbian forests" that "stretch on all sides indefinitely, leaving room only for a wide, meandering road" (Lamartine, 2006). A few years before Lamartine, Joakim Vujić and Otto Ferdinand Dubislav von Pirch had similar impressions when traveling through Serbia. Writing in 1826 during a journey through Serbia that lasted several months, Vujić, a Serbian writer from southern Hungary, left a number of notes about the Principality's "frightful forests" (Vujić, 1999), while in 1829, the Prussian officer Pirch left the most detailed data on forests. While on the road from Bel- 
grade to Smederevo he recorded that "on both sides of the road a ... forest was so thick ... that the human foot can't pass through," and, similarly, wrote about the "dark", "large" and "frightful" forests during the rest of his trip around Serbia (Pirh, 2012). Half a century later, shortly after independence, while traveling through the cultivated fields of Morava River valley, Sreten L. Popović recalled an old saying that, "it was once such a [thick] tangle of forest, spinney and bushes that not even a snake could be pulled out of it by its tail" (Popović, 1950).

Lamartine's romanticist enthusiasm, intertwined with the subjectivity of his memories as well as the travelogue literature, created a subsequent perception of Serbia as "a large forest garden" whose borders matched the boundaries of forested areas (Jekić, 1928). Literature from the first half of the $19^{\text {th }}$ century, which essentially dealt with areas along main roads and often in river valleys, led to the conclusion that forest covered the Principality not only on the mountain ranges, but "on the lowest platforms and valley bottoms" as well, as was later pointed out by Jovan Cvijić (Cvijić, 1922). According to Dušan Simeunović, conclusions about the forests of Serbia in the early $19^{\text {th }}$ century can also be made on the basis of research of various factors such as location and types of settlements, types of houses and building materials, the occupations and habits of the population, geographical terms derived from the word "forest", that manner in which and to what extent wood was used in everyday life, etc. (Simeunović, 1957).

However, the process of deforestation was already gaining pace by the time of Lamartines' journey through Serbia. The archpriest Matija Nenadović recalled in his memoirs in the 1830s that the deforested areas of the Morava and Mačva during the time of the First Serbian Uprising (1804-1813) were characterized by forests and spinneys so thick that a "pedestrian could not pass" (Nenadović, 1957). When writing about Serbia during the rule of Prince Miloš on the basis of contemporary sources, Tihomir Đorđević noted that "forests...were destroyed without order and without any economy," that they "were destroyed to help the spread of the old population, and the new to inhabit, and to create clear land for cultivation," while simultaneously "the forest was destroyed...for fences, and for firewood, and as fodder for livestock through the winter" (Đorđević, 1983). Thus, he described a wide range of reasons for such fast deforestation. The period from the acquisition of autonomy to the "wars of liberation and independence," as Serbian historiography called Serbo-Ottoman Wars of 18761878 , was marked by particularly intense deforestation. During his travels through Serbia in the 186os, Felix Kanitz, an Austrian travel writer, picturesque- ly noted that a "war was declared" on forests (Kanitz, 1868; Sundhaussen, 1989). The report on the state of forests in the Belgrade, Valjevo, Šabac and Rudnik districts from 1862, written by one of the head-chiefs of the Ministry of Finance, demonstrated that he was not exaggerating in his estimation. When describing the alarming situation in these districts, he concluded that "throughout Serbia...there is and there is not forest," because "observing from afar one might say the whole country is covered with forests; and when he enters the woods, one can see there is no real forest" because of continuous and uncontrolled exploitation by peasants (Report, 1863).

A paradigmatic example of the process of deforestation which attracted the attention of contemporaries probably due to the fact that it was a late example from the 1860 s and the 1870 s when the problem was generally obvious was that of Mt. Miroč (Krajina District). First, in 1855, the Serbian government settled Montenegrin families in the village of Petrovo Selo, and then in 1872 allowed the establishment of the village of Miročevo by Bulgarian refugees on the southern slope of the mountain (Jagodić, 2004). While warning about the problem of the "destruction of forest," one contemporary wrote that in the early 1860 os Miroč was an "immense, impenetrable ... mountain with branches all over the place, to Brza Palanka, Ključ and Donji Milanovac, almost to the Danube waterside," and that by the end of the 1870 "everywhere are fallows, fields and meadows, and the central and highest part of the mountain, where the village Miročevo was, had all been cut down and cleared". According to the description, the state of the mountain was such that it would no longer be profitable for the state to organize exploitation of the forest. "One who has an opportunity to observe the mountain or forest from higher ground...during the spring, summer, or autumn, can see smoke all around, like the mountain is on fire." (Bogdanović, 1880).

\section{Causes}

It is estimated that due to continued deforestation, the area covered by forest in the early 1870 s was for the first time smaller than that of cultivated land. The accelerated process of deforestation was the result of the Principality's dynamics of economic development after gaining autonomy. According to the opinion of Simeunović, the primary factor behind this was demographic (Simeunović, 1957). In a period of four decades the population of Serbia doubled-from 698,624 in 1834 to $1,353,890$ in 1874 -which led to the expansion of existing settlements and the establishment of new ones (Ljušić, 2001). Demographic growth imposed an ongoing necessity to provide sufficient quan- 
tities of food. In premodern, agrarian societies, this usually meant an increase in arable land. In the Serbian case, since the technological level of cultivation was low and showed slow developmental trends, this also included low yields per hectare, and the accelerated expansion of arable land with a poorly developed system of fallow or alternative means of adding nutrients necessary for maintaining the level of agricultural yield. Rapid expansion of arable land occurred primarily at the expense of forests or earlier deforested lands used as meadows and pastures. At the same time, the transition from animal husbandry to agriculture as the dominant economic activity narrowed the material basis for animal husbandry because of the conversion of meadows and pastures into fields, with further pressure increasing on the forest. All these factors were correlated and intertwined, thus marking the process of deforestation during the $19^{\text {th }}$ century in different ways, to varying degrees and in various areas (Simeunović, 1957).

The starting point for understanding of the processes or the dynamics of economic development and associated deforestation is the peasant economy as an essential segment of peasant societies formed due to the effect of various geographical, historical, economic and social conditions (climate, relief, methods of land acquisition, cultural systems, etc.) which determined their specificity. In contrast to international or national flow of goods and capital, a peasant economy is defined as a "culture of survival" (Mrgić, 2013) and a "process of being subjected to reproductive dynamics" (Harris, 1996). This is fundamentally different from capitalist farm management which is based on production for the market; therefore peasant agriculture can be viewed as existential in nature. This existential agriculture was the dominant feature of a peasant economy that defined its own agricultural system by correlating the number of mouths to feed with the number of hands needed for the job-hands that with processing of available land must meet necessary expectations, primarily financial, of the state's administrative system, the pressure of which slowly, but continuously intensified (Mendras, 1976).

On the existential level of agriculture, with the technology of cultivation on the same existential level, the "ocean of Serbian forests" was an obstacle that had to be overcome. The highest quality forests covered with trees most valuable for extractive animal husbandry, were at the same time on the most valuable soil for agricultural production. These were often in the river valleys, and especially in the Morava River valley. Deforestation was a necessity for Serbian peasants. Much later, the Serbian sociologist Sreten Vukosavljević wrote that when dividing or taking new uncultivated land, peasants were always more eager to take an area that was not covered by trees. In the first half of the $19^{\text {th }}$ century this possibility was rare. It could be said that in the first decades of the existence of the vassal principality, the construction of settlements and economic activity could not begin before clearing of the land of forests. As pointed out by Vukosavljević, the forest was "a torturous obstacle for creating a cultivating soil" and "to overpower the forest was one of the main cultural deeds of the first generations of settlers" (Vukosavljević, 2012).

At the same time, the attitude of the government, or the non-existence/negligence of legal regulations and the absence of organized forest management was undoubtedly one of the significant factors that affected the dynamics of deforestation. Based on the needs of the peasant society and the dominant features of his economic activity, forest legislation in the Principality of Serbia reflected a tendency to regulate the supply of timber for firewood and other forest products and the provision of sufficient quantities of fertile land necessary for preserving the continuity of the peasant economy. In the first half of the $19^{\text {th }}$ century forest management was predominantly determined by the importance of forests for extractive livestock breeding, particularly for pigs as the most important export good. The essence of later legislative activities was defined between the first known legislative act dealing with forests in 1820 (Petrović and Petrović, 1882) and the first act that explicitly dealt with forests after the adoption of the Constitution of 1839 (Collection of laws, 1880). This included forbidding the cutting down of acorn-rich forests (oak forests and European beech forests) which were fundamental for pig breeding (the most important export oriented economic activity), or only by special approval from local authorities. Other types of trees were available for ruination (Collection of laws, 1877).

After the decree of 1839, the government clarified and amended forest legislation on several occasions, essentially nullifying and disabling its basic purpose, which was protection of acorn-rich forests. Their preservation or extinction was closely related to the primary, demographic factor that led towards the expansion of existing settlements and the creation of new ones, as well as to the increase of arable land, mostly by clearing forests. When faced with the demographic challenge of an existential agriculture the state slowly relented.

A new legislative framework for forest management-or, to be more precise, its removal-issued by the laws of 1857 and 1861 reflected the process of transition from animal husbandry to agriculture as the dominant economic activity, followed by a narrowing of the material base of livestock breeding which increased pressure on the forest. Faced with the new 
needs of existential agriculture for arable land, the state defined a different place of forest after two decades of continuous deforestation. The provisions of the 1857 and 1861 laws legitimized the existing trend of deforestation by formulating a justification for it and creating a legislative framework, while the penalty provisions for uncontrolled deforestation proved to be ineffective in the long run (Collection of laws, 1853). According to Dušan Simeunović, the forest law from 1861, in force at the time of independence, didn't have "the character of forest laws in today's terms, but represented a set of rules governing the procedure for issuing timber from the forest and the procedure for granting the necessary area for clearing" (Simeunović, 1957). The law, therefore, reflected the essence of the pragmatic character of forest legislation within the value system of a peasant society where existential agriculture was the dominant economic activity, and reflected the necessity for legal regulation of the supply of timber for firewood and other forest products, and the provision of sufficient quantities of fertile land to preserve the continuity of the peasant economy. Starting from Simeunovićs remark that tracking the evolution of forest legislation is a good indicator of the attitude of the state towards forest preservation, it can be concluded that the governments' forest policies left the forest essentially unprotected.

\section{Consequences}

Due to the accelerated process of deforestation and the position of the state which failed to define a clear concept of forest preservation, negative effects were apparent long before independence. Erosion in deforested surfaces began to appear throughout Serbia. Contemporary writers remarked on the "rocky deserts" (Karić, 1887) and "the barren land where organic life had become extinct" (Prvo Pančićevo putovanje, 1914). In the 1862 report of the Ministry of Finance mentioned previously, attention was brought to the increasingly obvious problem of the deforestation of mountain slopes and to possible catastrophic long-term consequences (Report, 1863). A paradigmatic example in 1849 was a major erosion of arable land in the Užice district, in the rolling hills along the river Drina, where, according to reports, spring floods washed away more than a hundred acres of arable land (Miljković Katić, 2014). The Serbian botanist Josif Pančić had already noticed signs of erosion in the 1850s1, and in the 1870 s named parts of the Rudnik,

1 In 1856 Pančić, as a lecturer at the Great School in Belgrade, organized his first field trip around Serbia with students. In 1863 a new group of students traveled through Serbia. The texts that were the result of these field trips mention in many places soil erosion as a consequence of deforestation.
Čačak, Užice, Jagodina, Knjaževac and Krajina districts as the "hottest" spots with the highest level of erosion, adding that "these rocky terrains are so devastated and deprived of any useful flora, that the people who live there are facing the greatest scarcity in pasture and necessary forest products" (Pančić, 1893). In one of many typical descriptions in the 1862 report from the Ministry of Finance, Despotovac Gorge was described as "entirely rocky, in a way that one can see nothing but rock, and just here and there one can see a deserted $\log$ as a sad reminder that this area once flourished in the same way it's now turning into perfect desert," and that "as you enter the gorge, the desolation becomes even sadder, because apart from rocks constantly rolling into the valley, there's nothing more to see," and that "no one could believe man's hand is capable of producing such a terrible devastation" (Jekić, 1928)2.These processes were also noted by Kanitz who wrote, "we should not be surprised that Serbia, once a land so rich in woods, now has areas where shortages of firewood appear or threaten to appear in the near future" (Kanitz, 1868).

These processes were most obvious in the north of the country in areas marked in the 1850 s and the $1860 \mathrm{os}$ by significant growth in agricultural production, not only of maize as the dominant crop, but especially of grain, which is known for its fast depletion of nutrient levels in soil, and which required clearing new areas to maintain and increase the level of production. One consequence of the process of deforestation and land clearing that was most evident in the decade before independence, even for peasants, was the problem of providing the peasant society's basic needs: firewood, cattle fodder, etc. According to testimonies from the 1860 s, in Kitog, located in the Mačva region and the area mentioned by Archpriest Matija Nenadović as being covered by forest and bushes at the time of the First Serbian Uprising (Nenadović, 1957), "there is no wood suitable for a yoke to cut" and "peasants have problems finding firewood, so they have to go to the mountains in bad weather and are forced to bring firewood from far away" (Statistics, 1870). This was not an isolated case. In periodical reports on the condition of the peasant economy from the 1860 os and the 1870 s, especially in the municipalities of the northern districts, there were frequent observations indicating the absence of forests, or that they had been diminished.

\footnotetext{
2 The descriptions of other areas he visited were similar. The status of the forest cover of any particular mountain, and the potential risk of erosion, was assessed by looking at the streams below. "I didn't have to observe Venčac (Kragujevac District M. S.) long. It was enough to observe the streams coming out of it, to know immediately what condition the forest was in. Large amount of sand and rocks, brought by water from the highest peaks of the mountain is proof that there is no forest which should be there."
} 
After erosion, the most significant consequence of deforestation was periodical flooding. In the 1880 s Vladimir Karić noted that, "today there are mountainous areas without woods that have become rocky deserts from which streams after heavy rains bring stones and overwhelm fertile fields and plains" (Karić, 1887). Mountain regions became areas of torrents, while the plains collected water. Water quickly flowed into deforested areas after heavy rainfall. As a result, the second half of the $19^{\text {th }}$ century was marked by three major floods: the first in 1864, and then again in 1871 and 1896 , but the spring and autumn torrents and smaller floods became a regular phenomenon the Serbian peasant could be sure of.

An additional consequence of the varying intensity of deforestation was the phenomenon of an unevenness in forest dispersion. The forests mainly disappeared in the river valleys and fertile plains of northern Serbia (Mačva, Stig, the Kolubara Valley, and the Danube and Morava river valleys in the Smederevo district), and deforestation was also intense in the river valleys in the interior of the country. Forests were mostly devastated in the vicinity of settlements, but the need for arable land forced further deforestation of more remote places. Sources from the 1860 s and the 1870 s mention the edge of the forests continuously moving to higher altitudes. On the other hand, even though the literature claims that in the early 1870 s the amount of cultivated land exceeded the total area covered by forest, a high percentage of forestation on a national level in the 1870 s was the result of difficult access to certain sparsely populated areas at higher altitudes (i.e. Kopaonik, Tara, etc.) covered by forests and owned by the state, and the fact that, in spite of the appearance of the first sawmills in the 186os, organized exploitation of forests still didn't exist (Simeunović, 1957). It could be said that, to a certain extent, the consequences of the process of deforestation coincided with Serbia's geographical characteristics, and that the largest forest areas managed to survive on its southern borders, in regions at higher altitudes and, of course, with the lowest population rates.

Awareness of the negative consequences of deforestation was present at the beginning of the 1870 s partially as a result of the previously mentioned publications, and, in particular, after two major floods in 1864 and 1871 . However, it was only present at the level of the educated elite. Efforts by the Ministry of Finance at the beginning of the 1870 s to encourage reforestation were a reflection of this awareness. In 1873 the Ministry devoted particular attention to the implementation of forest legislation and to warning local authorities "not to allow trees to be cut down where the forest is already thin, particularly in the cliff areas, where heavy rain could cut ravines and to bring down earth, sand and rocks onto the valley, or where the land is rocky, so the forest is hard to raise when the old one is destroyed" (Collection of laws, 1886) and stressed the importance of the law issued in 1872 according to which local authorities were obliged to support reforestation in general, "and especially on the rocky hills and slopes, from where the pouring water is destroying roads and overwhelming fertile land with stones and sand" (Collection of laws, 1872).

One of the questions in a questionnaire from the Ministry of Finances for the annual reports on the state of the peasant economy dealt with data about reforestation. The response from local authorities was almost always negative: peasants and local authorities were not doing anything to implement the legislation from the beginning of the 1870 s. Forced by the consequences of deforestation and the inability to promote planting of new trees, before the wars with Ottoman Empire the state supported the idea of establishing a forest service "to raise and cultivate forest and to organize logging in the country's forests" (Collection of laws, 1886).3 However, efficient regulation of forest service requires time. As was previously mentioned, the state waited until the end of 1899 to order the organization of forest management, despite the provisions of the Law on Forests of 1891, which had provided a legal framework for this.

\section{Conclusions}

Rapid demographic growth, accompanied by the expansion of arable land due to a gradual transition from animal husbandry to agriculture as the dominant form of economy led to a vigorous increase in the process of deforestation in the period between gaining autonomy and the wars against the Ottoman Empire. Despite certain steps, in the existing context of peasant society the legal protection of forests was not a priority for the government. The government's primary objective was to regulate the process of deforestation in order to ensure society's existential agriculture to function. In the first phase the main task was to preserve acorn-rich forests as a prerequisite for animal husbandry, especially for the purpose of breeding pigs for export. Gradually, the focus was transferred onto securing sufficient quantities of fertile land necessary for preserving the continuity of the peasant economy in a time of transition from animal husbandry to agriculture as the dominant economic activity. Suprem-

\footnotetext{
3 According to known historical sources, the state made its first unsuccessful attempt to organize a forest service by appointing foresters in 1836 (which lasted only one year). In 1859 the Ministry of Finances advised local authorities to appoint foresters if they were capable of financing them from their own funds.
} 
acy accomplished by agriculture in the beginning of the 1870 s was realized at the expense of forests because the increase in agricultural yields in a peasant existential economy characterized by underdeveloped agricultural techniques meant a continuous expansion of arable land. Thus, the example of the Principality of Serbia confirms the regularity once noted by the British geographer Ian G. Simmons, who claimed that in agrarian economies competition between the usufruct of the forest and its potential as agricultural land regularly ends with the removal of the forest (Simmons, 2008).

Even though there are no exact statistical data for the deforestation process in the $19^{\text {th }}$ century, based on an analysis of existing historical sources and literary works, it can be concluded that the pattern of the destruction of forests, which lead to long term negative side effects such as erosion and floods, was formed during the first decades of the modern Serbian state in the $19^{\text {th }}$ century. An interesting topic for future research could be to focus on different parts of Serbia, particularly those that were affected by the floods in 2014, and to compare archival and literary sources from the $19^{\text {th }}$ century with detailed statistical data on forests from the first half of the $2 \mathrm{O}^{\text {th }}$ century, and then with its evolution during the second half of the $20^{\text {th }}$ century, with a particular focus on the issue of negative side effects and the (non)existence of state driven policies to prevent such a development.

\section{References}

Bogdanović, V. S. 188o. Destruction of our forests, Težak, 2, 14-16 (in Serbian)

Buxton, N. 1908. Balkan Geography and Balkan Railways, The Geographical Journal, 32/3, 217-234.

Cvijić, J. 1922. The Balkan Peninsula and lands of the South Slavs: foundations of anthropogeography, I. Dubislav Pirh, O. 2012. A journey through Serbia in 1829. Službeni glasnik, Belgrade, 217 pp. (in Serbian)

Državna štamparija Kraljevine SHS, Belgrade, 418 pp. (in Serbian)

De Lamartine, A. 2006. Writings about Serbs: excerpts from Lamartins works. Utopija, Belgrade, 273 pp. (in Serbian)

Đorđević, T.P. 1922. From the Serbia of Prince Miloš: cultural situation from 1815 till 1839. Izdavačka knjižarnica Gece Kona, Belgrade, 236 pp. (in Serbian)

Harris, D. R. (ed.) 1996. The Origins and Spread of Agriculture and Pastoralism in Eurasia. UCL Press, London, $594 \mathrm{pp}$.

Jagodić, M. 2004. The settlement of the Principality of Serbia 1861-1880, Istorijski institut, Belgrade 2004, 204 pp. (in Serbian)
Jekić, J. 1928. Contributions to the history of forestry management in Serbia, Belgrade, 357 pp. (in Serbian)

Kanitz, F. 1868. Serbien: historisch-ethnographische Reisestudien. Verlagsbuchhandlung von Hermann Freis, Leipzig, 744 pp.

Karić, V. 1887. Serbia: a description of the land, people and state. Kraljevsko-srpska državna štamparija, Belgrade, 935 pp. (in Serbian)

Ljušić, R. 2001. History of Serbian statehood, II. Srpska akademija nauka i umetnosti - Beseda, Novi Sad, 408 pp. (in Serbian)

Mendras, H. 1976. Sociétés paysannes: éléments pour une théorie de la paysannerie, Armand Collin, Paris, $236 \mathrm{pp}$.

Mihajlović, I.M. 1982. Forest management of Timočka Krajina 1833-1979. Šumarsko-industrijski kombinat “Južni Kučaj”, Zaječar, 243 pp. (in Serbian)

Miljković Katić, B. 2014. Agriculture of the Principality of Serbia (1834-1867). Istorijski institut, Belgrade, 382 pp. (in Serbian)

Mrgić, J. 2013. Land and people: from the history of the environment in the Western Balkans. Equilibrium, Belgrade, $158 \mathrm{pp}$. (in Serbian)

Nenadović, M. 1957. Memoirs, Matica srpska - Srpska književna zadruga, Novi Sad - Belgrade, 256 pp. (in Serbian)

Pančić J. 1893. From nature: minor works of Dr. Josif Pančić. Srpska književna zadruga, Belgrade, 182 pp. (in Serbian)

Petrović, V. J. - Petrović, N. J. (eds.) Sources for the history of the Kingdom of Serbia: the time of the first rule of Prince Miloš Obrenović. Državna štamparija, Belgrade 1882, 488 pp. (in Serbian)

Popović, K. 1867. Lyceum cadets' journey through Serbia, 1863 . Državna štamparija, Belgrade, 173 pp. (in Serbian)

Popović, S.L. 1950. Journey through new Serbia (in 1878 and 1880). Srpska književna zadruga, Belgrade 1950, 567 pp. (in Serbian)

Simeunović, D.S. 1957. Causes of the disapearance of forests in Serbia in the $19^{\text {th }}$ century. Zadružna knjiga, Belgrade, 243 pp. (in Serbian)

Simmons, I.G. 2008. Global Environmental History: 10,000 BC to AD 2000. University of Chicago Press - Edinburgh University Press, Chicago, 288 pp.

Sundhaussen, H. 1989. Historische Statistik Serbiens 1834-1914: mit europäischen Vergleichsdaten. Oldenbourg, München, $645 \mathrm{pp}$.

Škorić, A. 1977. Types of soils. Liber, Zagreb, 134 pp. (in Croatian)

Vlahović, P. 2011. Serbia: land, people, life, customs. Službeni glasnik, Belgrade, 484 pp. (in Serbian)

Vujić, J. 1999. A journey through Serbia. Lio, Gornji Milanovac, 272 pp. (in Serbian) 
Vukosavljević, S.V. 2012. History of peasant society, III: Sociology of peasant works. Službeni glasnik, Belgrade, 596 pp. (in Serbian)

\section{Other sources}

1853 Collection of laws and decrees, V. Državna štamparija, Belgrade, 314 pp. (in Serbian)

1862 Collection of laws and decrees, XIV. Državna štamparija, Belgrade, 257 pp. (in Serbian)

1870 Statistics of Serbia, IV. Državna knjigopečatnja, Belgrade, 160 pp. (in Serbian)

1872 Collection of laws and decrees, 25. Državna štamparija, Belgrade, 96 pp. (in Serbian)

1877 Collection of laws and decrees, 30. Državna štamparija, Belgrade, 404 pp. (in Serbian)

1880 Collection of laws and decrees, I. Državna štamparija, Belgrade, 211 pp. (in Serbian)
1886 Collection of laws, regulations, orders and instructions about forests in the Kingdom of Serbia. Državna štamparija, Belgrade, 79 pp. (in Serbian)

1894 Inventory of cultivated land in the Kingdom of Serbia, 1889, Državna štamparija Kraljevine Srbije, Belgrade, 237 pp. (in Serbian)

1906 Statistical yearbook of the Kingdom of Serbia, VIII/1903, Državna štamparija Kraljevine Srbije, Belgrade, 770 pp. (in Serbian)

1907 Reports submited to the Minister of National Economy on work in 1906 (Report on work of Forestry Department). Državna štamparija, Belgrade, 170 pp. (in Serbian)

1989 History of Titovo Užice (to 1918), I. Istorijski institut, Titovo Užice, 995 pp. (in Serbian) 